\title{
Formulation of the CBC-model for modelling the contaminants and footprints in natural attenuation of BTEX
}

\author{
Max Maurer ${ }^{1, *} \&$ Bruce E. Rittmann ${ }^{2}$ \\ ${ }^{1}$ Engineering Science Dept., EAWAG, Überlandstrasse 133, CH-8600 Dübendorf, Switzerland (*author for cor- \\ respondence: e-mail: max.maurer@eawag.ch); ${ }^{2}$ Environmental Engineering and Science Probram, Northwestern \\ University, 2145 Sheridan Road, Evanston, IL 60208-3109, USA (e-mail: b-rittmann@northwestern.edu)
}

Accepted 27 June 2003

Key words: calcite, dissolution, fermentation, footprints, intrinsic bioremediation, iron reduction, methanogenesis, natural attenuation, precipitation, sulfate reduction, sulfide

\begin{abstract}
This paper provides the details of the Coupled Biological and Chemical (CBC) model for representing in situ bioremediation of BTEX. The CBC model contains novel features that allow it to comprehensively track the footprints of BTEX bioremediation, even when the fate of those footprints is confounded by abiotic reactions and complex interactions among different kinds of microorganisms. To achieve this comprehensive tracking of all the footprints, the CBC model contains important new biological features and key abiotic reactions. The biological module of the CBC-model includes these important new aspects: (1) it separates BTEX fermentation from methanogenesis, (2) it explicitly includes biomass as a sink for electrons and carbon, (3) it has different growth rates for each biomass type, and (4) it includes inhibition of the different reactions by other electron acceptors and by sulfide toxicants. The chemical module of the $\mathrm{CBC}$-model includes abiotic reactions that affect the footprints of the biological reactions. In particular, the chemical module describes the precipitation/dissolution of $\mathrm{CaCO}_{3}, \mathrm{Fe}_{2} \mathrm{O}_{3}, \mathrm{FeS}, \mathrm{FeS}_{2}$, and $\mathrm{S}^{\circ}$. The kinetics for the precipitation/dissolution reactions follow the critical review in Maurer \& Rittmann (2004).
\end{abstract}

\section{Introduction}

Monitoring and its interpretation are the keys for assessing in-situ bioremediation, especially for natural attenuation. The biological conversion of a pollutant is connected with a stoichiometric consumption and production of several other compounds, called footprints of the biodegradation reaction. This knowledge, properly quantified in a mathematical model, creates a body of evidence documenting the efficiency of bioremediation (NCR 1993, 2000; Maurer \& Rittmann 2004). To be able to exploit this information, the chemical fate, as well as the biological fate, of these substances has to be known. For example, precipitation and dissolution of solids, like iron sulfide or calcium carbonate, affect the fate of the biodegradation footprints $\mathrm{Fe}(\mathrm{II})$, inorganic carbon, and alkalinity (Maurer \& Rittmann 2004). Furthermore, the biolo- gical model must provide an accurate representation of the types of microbially catalysed reactions.

Currently available models (BIOPLUME III, Rafai et al. 1998; RT3D, Clement 1997; UTCHEM, Pope et al. 1999; TBC, Schäfer et al. 1998a, b) concentrate mainly on groundwater transport and have simplified models of the biological processes and no chemical processes. They do not provide the biological or chemical features needed to accurately represent the fate of footprints of BTEX bioremediation. To overcome this limitation, we present here the Coupled Biological and Chemical (CBC) model for the comprehensive quantification of BTEX bioremediation. The CBC model includes the key abiotic chemical reactions that affect the fate of the footprints for BTEX biodegradation, and it also provides a realistic representation of the microbiological reactions. The scientific foundation for the new features in the CBC model is summarized in Maurer \& Rittmann (2004). We demonstrate im- 
portant predictions of the CBC model in a subsequent work (Rittmann and Maurer, in preparation).

The goal of the CBC model is to have an explicit coupling of the key microbiological and chemical reactions that can affect the fate of BTEX and its biodegradation footprints during natural attenuation. Achieve this goal makes possible a quantitative connection between loss of BTEX and the appearance of BTEX-biodegradation footprints, even when the footprints are affected by other reactions.

\section{Model overview}

The CBC model focuses on the saturated zone of the groundwater system and assumes that it is a closed system (no gas exchange). In this paper, we describe all of the reaction processes. Transport processes are not described here.

\section{Model reactions}

The CBC model contains the following kinetically controlled microbiological processes:

- BTEX (hydrocarbon) biodegradation by bacteria that respire the following electron acceptors: oxygen $\left(\mathrm{O}_{2}\right)$, nitrate $\left(\mathrm{NO}_{3}^{-}\right)$, iron(III) $\left(\mathrm{Fe}_{2} \mathrm{O}_{3}\right)$, and sulfate $\left(\mathrm{SO}_{4}^{2-}\right)$.

- Fermentation of BTEX to acetate and hydrogen $\left(\mathrm{H}_{2}\right)$.

- Oxidation of acetate by bacteria using the same four electron acceptors.

- Methanogenesis (methane formation) by acetate cleavage.

- Methanogenesis by oxidation of $\mathrm{H}_{2}$ and reduction of inorganic carbon.

- Decay of the microorganisms

The CBC model also contains five kinetically controlled precipitation/dissolution reactions:

- Dissolution and precipitation of calcium carbonate $\left(\mathrm{CaCO}_{3(\mathrm{~s}))}\right.$, which buffers the $\mathrm{pH}$, changes the alkalinity and inorganic-carbon concentrations, and affects the dissolved calcium $\left(\mathrm{Ca}^{2+}\right)$ concentration.

- Conversion of FeS into the thermodynamically stable pyrite $\left(\mathrm{FeS}_{2}\right)$, which brings about loss of $\mathrm{H}_{2} \mathrm{~S}$, but is an abiotic source of $\mathrm{H}_{2}$.

- Reductive dissolution of solid iron(III) by oxidation of sulfide, which consumes $\mathrm{H}_{2} \mathrm{~S}$ while producing dissolved $\mathrm{Fe}^{2+}$ and $\mathrm{SO}_{4}^{2-}$ or $\mathrm{S}_{8}$ (elemental sulfur).
The CBC model also contains a set of equilibrium reactions needed to describe the aqueous chemistry. They involve speciation of the carbonate and sulfide systems and the precipitation and dissolution of iron(II) and sulfide as amorphous iron monosulfide (FeS). These processes decrease the biodegradation footprints $\mathrm{Fe}^{2+}$ and $\mathrm{HS}^{-}$.

\section{Model components}

The CBC model contains 16 dissolved components: BTEX, acetate, oxygen, nitrate, ammonium, sulfate, methane, hydrogen, calcium, iron(II), inorganic carbon, and inorganic sulfide. Inorganic carbon and sulfide are partitioned into different species according to equilibrium: $\mathrm{H}_{2} \mathrm{CO}_{3}, \mathrm{HCO}_{3}^{-}, \mathrm{CO}_{3}^{2-}, \mathrm{H}_{2} \mathrm{~S}, \mathrm{HS}^{-}$, and $\mathrm{H}^{+}$. BTEX, $\mathrm{S}_{\mathrm{HC}}$, is lumped together and treated as a single organic substance, while acetate $\left(\mathrm{CH}_{3} \mathrm{CO}_{2}^{-}\right)$, $\mathrm{S}_{\mathrm{F}}$, is assumed to be the organic product from BTEX fermentation.

The model distinguishes five unique biomass types:

- Fast growing heterotrophic bacteria that respire oxygen and nitrate, $\mathrm{X}_{\mathrm{BO}}$, are able to utilise BTEX and acetate as electron donors and carbon sources. When oxygen and nitrate are absent, these microbes are able to ferment BTEX to acetate and $\mathrm{H}_{2}$.

- Sulfate-reducing bacteria, $\mathrm{X}_{\mathrm{BS}}$, are able to reduce sulfate and use BTEX or acetate as electron donor and carbon source.

- Iron-reducing bacteria, $\mathrm{X}_{\mathrm{BF}}$, are able to access solid iron(III) and use it as an electron acceptor. BTEX and acetate serve as electron donors and carbon sources.

- Acetoclastic methanogens, $\mathrm{X}_{\mathrm{BAc}}$, cleave acetate to methane and inorganic carbon.

- Hydrogen-oxidizing methanogens, $\mathrm{X}_{\mathrm{BH}_{2}}$, produces methane by using hydrogen as an electron donor and inorganic carbon as electron acceptor and carbon source.

The CBC model has five inorganic solid phases: calcium carbonate $\left(\mathrm{CaCO}_{3}\right), \mathrm{X}_{\mathrm{CaCO}_{3}}$; iron(III) oxide $\left(\mathrm{Fe}_{2} \mathrm{O}_{3}\right), \mathrm{X}_{\mathrm{Fe}_{2} \mathrm{O}_{3}}$; iron(II) monosulfide $(\mathrm{FeS}), \mathrm{X}_{\mathrm{FeS}}$; pyrite $\left(\mathrm{FeS}_{2}\right), \mathrm{X}_{\mathrm{FeS}_{2}}$; and elementary sulfur $\left(\mathrm{S}^{0}\right), \mathrm{X}_{\mathrm{S}}$.

\section{Model kinetics expressions}

The rate terms for microbiological reactions are formulated in a way that includes how the rates of biomass synthesis and electron-donor utilization are 
controlled by the concentrations of the cells themselves, their electron donor and electron acceptor, their nitrogen source, and any inhibitory chemical species. The rates of production or consumption of other chemical species involved in the microbiological reactions (e.g., inorganic carbon, ammonium nitrogen, $\mathrm{Fe}(\mathrm{II})$, and sulfide) are computed from stoichiometry.

The rate terms for abiotic precipitation or dissolution of the inorganic solid species are taken directly from the review by Maurer \& Rittmann (2004).

The CBC model does not include the re-oxidation of these terminal reduced products: methane, sulfide, and iron(II). Re-oxidation might occur if groundwater containing these reduced products was mixed with oxygenated water.

The next section describes the details of how the CBC model is formulated. Appendix 1 lists all the variables, their symbols, and their definitions. Appendix 2 lists the standard values for all the parameters mentioned in the next section.

\section{Modelling the microbiological reactions}

Table 1 lists all the kinetic expression used in the microbiological model. Table 2 is a matrix that shows the stoichiometry that links the different components involved in the microbiological reactions. The following sections describe the key features of the kinetics and stoichiometric expressions. All nomenclature used in the CBC is defined in Appendix 1, while Appendix 2 gives the numerical values and units for all parameters.

\section{Kinetic format}

All rates of biomass synthesis and donor utilization are based on a modified Monod equation that takes into account the effects of multiple substrates, nutrients, and inhibitors (Henze et al. 2000; Bae \& Rittmann 1996; Rittmann \& McCarty 2001). For biomass synthesis (processes B1-B5 in Table 1), the rate expression is of the form

$$
\rho_{i}=\mu_{i} \cdot[\text { modified Monod terms }]_{i} \cdot X_{i}
$$

in which $\rho_{i}=$ the growth rate of biomass type $i$ $\left[\mathrm{M}_{\mathrm{C}} \mathrm{d}^{-1}\right], \mu_{i}=$ the maximum specific growth rate of biomass type $i\left(\mathrm{~d}^{-1}\right), X_{i}=$ the concentration of biomass type $i\left(\mathrm{M}_{\mathrm{C}}\right)$, and [modified Monod terms] $i=$ the set of hyperbolic terms needed to describe how substrates, nutrients, and inhibitors control the overall rate for biomass type $i$ [dimensionless]. The modified Monod terms are described below and shown in Table 1. In order to calculate a specific substrate utilization rate, the rate from Table 1 is multiplied with the corresponding stoichiometric expression in Table 2. For example, the oxygen consumption rate by the fast-growing heterotrophs, $\rho_{\mathrm{O}}\left[\mathrm{M}_{\mathrm{O}_{2}} \mathrm{~d}^{-1}\right]$, is given with:

$$
\begin{gathered}
\rho_{\mathrm{O}}=\underbrace{-\left(\frac{i_{\mathrm{HC}}}{Y_{\mathrm{O}}}-i_{\mathrm{XB}}\right)}_{\begin{array}{c}
\text { Stoichiometric coefficient } \\
\text { (Table } 2 \text { for } \mathrm{S}_{2} \text { and } \mathrm{B} 1
\end{array}} \\
\cdot \mu_{\mathrm{O}, \mathrm{F}} \cdot \frac{\mathrm{S}_{\mathrm{O}}}{\mathrm{K}_{\mathrm{O}}+\mathrm{S}_{\mathrm{O}}} \cdot \frac{\mathrm{S}_{\mathrm{HC}}}{\mathrm{K}_{\mathrm{HC}}+\mathrm{S}_{\mathrm{HC}}} \cdot \\
\\
\underbrace{\frac{\left(\mathrm{S}_{\mathrm{NH}}+\mathrm{S}_{\mathrm{NO}}\right)}{K_{\mathrm{N}}+\left(\mathrm{S}_{\mathrm{NH}}+\mathrm{S}_{\mathrm{NO}}\right)} \cdot \frac{\mathrm{S}_{\mathrm{HC}}}{\mathrm{S}_{\mathrm{F}}+\mathrm{S}_{\mathrm{HC}}} \cdot \mathrm{X}_{\mathrm{BO}}}_{\text {Rate expression for } \mathrm{B} 1 \text { (aerobic growth) in Table } 1}
\end{gathered}
$$

The following types of hyperbolic functions are multiplied together make up the modified Monod term:

- Limitation by an electron-donor or electronacceptor substrate $S: S /\left(K_{S}+S\right)$. This is the common Monod expression for saturation kinetics by a donor and acceptor (Bae \& Rittmann 1996).

- Inhibition by an inhibitor I: $\mathrm{K}_{\mathrm{I}} /\left(\mathrm{K}_{\mathrm{I}}+\mathrm{I}\right)$. This form represents inhibition that is non-competitive and reversible. For example, $\mathrm{K}_{\mathrm{O}} /\left(\mathrm{K}_{\mathrm{O}}+\mathrm{S}_{\mathrm{O}}\right)$ in process B2 (Table 1) shows how oxygen inhibits anaerobic BTEX degradation, where $\mathrm{S}_{\mathrm{O}}$ is the oxygen concentration and $\mathrm{K}_{\mathrm{O}}$ is the inhibition coefficient.

- Modulation between two donor substrates $\left(S_{1}\right.$ and $\left.\mathrm{S}_{2}\right)$ by the same type of microorganisms: $\mathrm{S}_{1} /\left(\mathrm{S}_{1}+\right.$ $\left.\mathrm{S}_{2}\right)$. For example, $\mathrm{S}_{\mathrm{HC}} /\left(\mathrm{S}_{\mathrm{F}}+\mathrm{S}_{\mathrm{HC}}\right)$ in process $\mathrm{B} 2$ shows how acetate $\left(\mathrm{S}_{\mathrm{F}}\right)$ reduces the utilisation rate of BTEX $\left(\mathrm{S}_{\mathrm{HC}}\right)$ and correspondingly, the rate of B14 is limited with the modulation term $\mathrm{S}_{\mathrm{F}} / \mathrm{S}_{\mathrm{F}}$ $+\mathrm{S}_{\mathrm{HC}}$ ). Modulation guarantees that the growth rate of biomass growing on two substrates cannot exceed the microorganism's maximum specific growth rate.

\section{Decay of biomass}

The loss of active biomass is a first-order process for each biomass type $\left(X_{i}\right)$ and with a rate coefficient $b_{\mathrm{Bi}}\left(\mathrm{d}^{-1}\right)$. Processes B6-B10 in Table 1 are the decay terms. A fraction of the decayed biomass $\left(\gamma_{i}\right.$ in Table 2 ) is recalcitrant and produces inactive biomass solid. Inactive biomass is no longer tracked by the model. 
Table 1. Kinetics of the biological processes. The corresponding stoichiometry is given in Table 2

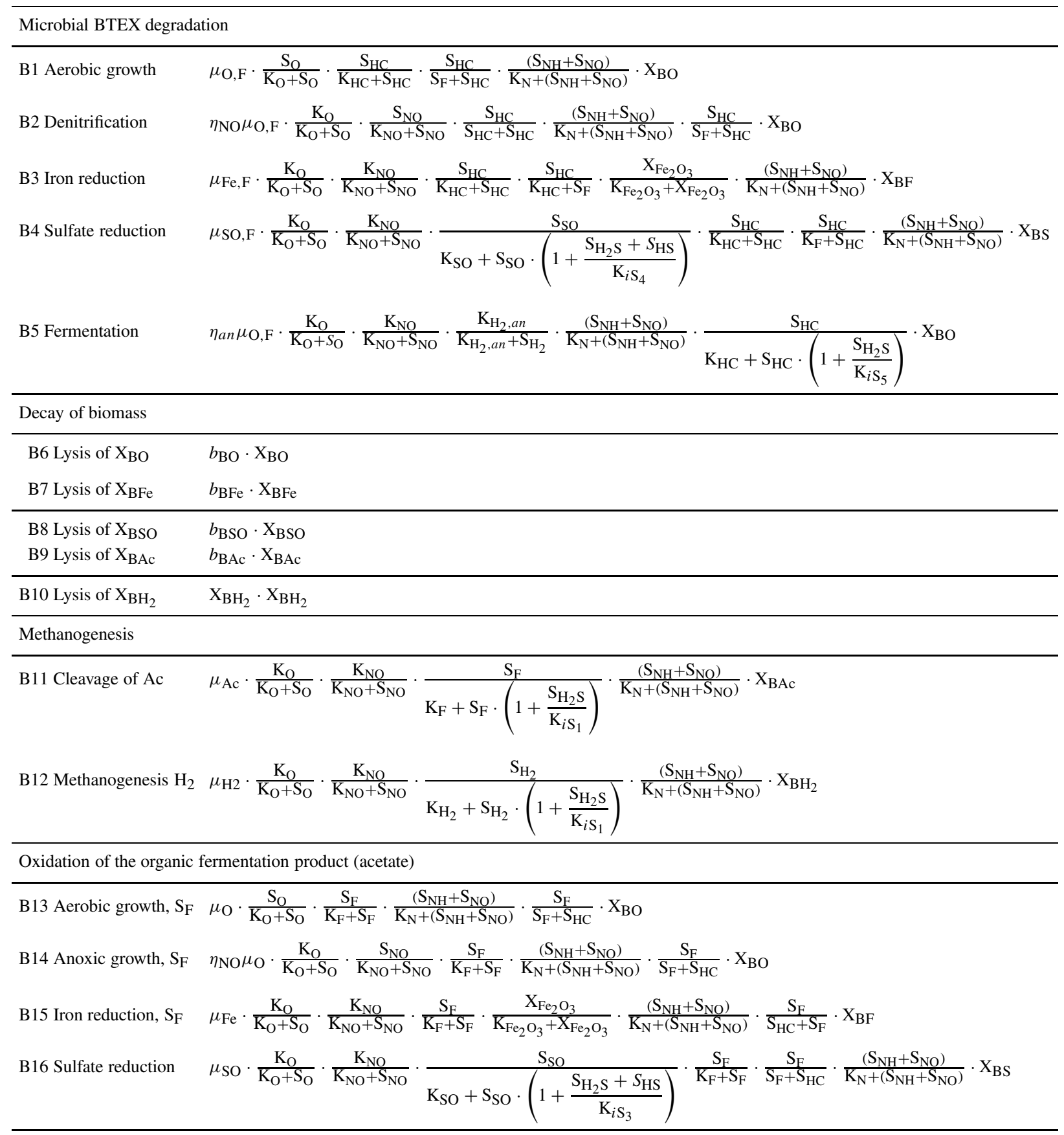




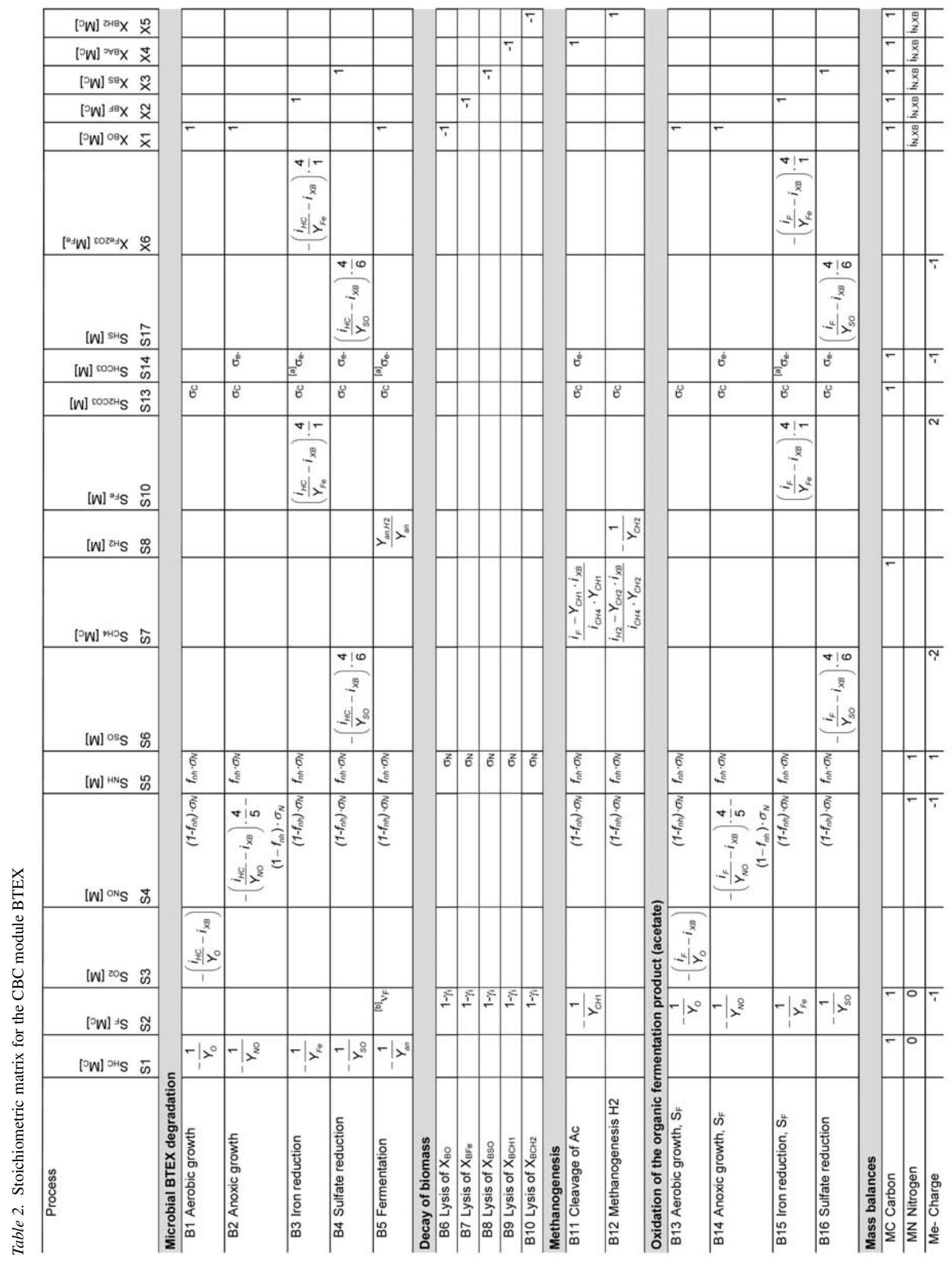


The decay of biomass is not connected directly to consumption of an electron acceptor. Instead, $\left(1-\gamma_{i}\right)$ of the lost biomass is assumed to be released as acetate, which is a donor substrate.

\section{Temperature corrections}

The maximum growth rates $\left(\mu_{I}\right)$ and the decay rates $\left(b_{\mathrm{B}}\right)$ are corrected for the temperature according to a modified Arrhenius equation:

$$
\mu\left(T_{2}\right)=\mu\left(T_{1}\right) \cdot e^{\lambda \cdot\left(T_{2}-T_{1}\right)}
$$

where $\mu\left(T_{2}\right)$ and $\mu\left(T_{1}\right)$ are the maximum growth rate at temperature $T_{2}$ and $T_{1}$ respectively, and $\lambda$ is the rate specific temperature coefficient $\left[{ }^{\circ} \mathrm{C}^{-1}\right]$.

\section{Stoichiometry}

Table 3 presents the stoichiometry for all of the catabolic reactions, along with standard Gibbs free energy values. Toluene represents BTEX, while acetate is assumed to be the only organic fermentation product.

- Growth yields: No growth yields are reported in the literature for mixed cultures degrading BTEX. Pure-culture studies for benzene and toluene show little variations between the two substrates, but significant differences among various microbial cultures (Reardon et al. 2000). The suggested aerobic growth yield $Y_{\mathrm{O}}=0.5 \mathrm{~mol}_{\mathrm{C}} \mathrm{mol}_{\mathrm{C}}^{-1}$ is an average value from several pure culture studies. For nitrate respiration, the yield is between 60 and $80 \%$ of the yield determined with oxygen as electron acceptor (e.g. Orhon et al. 1996; Kuba et al. $1996)$, and we use $80 \%\left(Y_{\mathrm{NO}}=0.8 \cdot Y_{\mathrm{O}}\right)$. The yield for iron reduction $\left(Y_{\mathrm{Fe}}=0.07 \mathrm{~mol}_{\mathrm{C}} \mathrm{mol}_{\mathrm{C}}^{-1}\right)$ is taken from a study with a pure culture of Shewanella oneidensis strain MR-1 (Kostka et al. 2002). The growth yield for sulfate reduction $\left(Y_{\mathrm{SO}}\right)$ is assumed to be proportional to the Gibbs free energies $\left(\Delta G_{f}\right)$ for sulfate and oxygen reductions in Table 3 . The growth yield for fermentation $\left(Y_{\text {an }}\right)$ is 0.076 and deduced from Schink (1997) and Thauer et al. (1977).

- Oxygen demand (stoichiometric parameters $i_{\mathrm{HC}}$ and $i_{\mathrm{XB}}$ in Table 2): To determine the amount of electron acceptor, the reduction equivalent of BTEX and the biomass have to be known. The values in Table 4, expressed as mole oxygen per mole carbon, reflect the theoretical chemical oxygen demand (COD) of the compounds. These values can be obtained by applying the methods described by
Reichert et al. (2001) or Henze et al. (2000). Because the $\mathrm{CBC}$ model does not distinguish among the BTEX components, $i_{\mathrm{HC}}$ is calculated from the fractions of the BTEX mixture. (i.e. $60 \%$ benzene and $40 \%$ toluene: $i_{\mathrm{HC}}=0.6 \cdot 1.25+0.4 \cdot 1.29$ $\operatorname{mol}_{\mathrm{O}_{2}} \operatorname{mol}_{\mathrm{C}}^{-1}$ ).

- Nitrogen uptake (stoichiometric parameter $f_{n h}$ in Table 2): In order to ensure that synthesis of biomass can consume $\mathrm{NO}_{3}^{-}$or $\mathrm{NH}_{4}^{+}$(or both) as the $\mathrm{N}$ source, the stoichiometric coefficient $f_{n h}$ is used to modulate the flow of synthesis $\mathrm{N}$ according to the availability of $\mathrm{NH}_{4}^{+}-\mathrm{N}$. The coefficient is defined as $f_{n h}=\mathrm{S}_{\mathrm{NH}} /\left(\mathrm{K}_{\mathrm{N}}+\mathrm{S}_{\mathrm{NH}}\right)$, where $\mathrm{S}_{\mathrm{NH}}$ is the ammonium concentration and $\mathrm{K}_{\mathrm{N}}$ the half saturation coefficient for nitrogen. When the $\mathrm{NH}_{4}^{+}$ concentration is high, all of the synthesis $\mathrm{N}$ comes from $\mathrm{NH}_{4}^{+}$, the more favourable $\mathrm{N}$ source. $\mathrm{NO}_{3}^{-}$is used as the $\mathrm{N}$ source only when $\mathrm{NH}_{4}^{+}$is at a low concentration.

\section{Types of inhibition}

Sulfide is relatively toxic due to its ability to form strong complexes with essential metal-containing compounds in the cell (e.g., iron in cytochromes). Sulfide can inhibit fermenters, sulfate reducers, and acetoclastic and hydrogen-oxidising methanogens. Following the experimental results and discussion of Maillacheruvu \& Parkin (1996), the CBC model assumes that $\mathrm{H}_{2} \mathrm{~S}$ inhibits methanogens and fermenters, whereas total sulfide concentration is toxic to sulfatereducing organisms. The inhibition is implemented into the rate expression by using a non-competitive, reversible approach (see Table 1 the hyperbolic terms for acetate $\left(\mathrm{S}_{\mathrm{F}}\right)$ and hydrogen $\left(\mathrm{S}_{\mathrm{H}_{2}}\right)$ in the processes for 'Methanogenesis').

The other growth processes are assumed to be inhibited according to the following scheme: nitrate respiration (B12) is inhibited by oxygen; iron reduction (B3) is inhibited by oxygen and nitrate; sulfate reduction (B4) is inhibited by oxygen, nitrate, and sulfide $\left(\mathrm{H}_{2} \mathrm{~S}+\mathrm{HS}^{-}\right)$; and fermentation (B5) is inhibited by oxygen, nitrate, hydrogen, and dihydrogen sulfide $\left(\mathrm{H}_{2} \mathrm{~S}\right)$.

\section{Kinetics for iron(III) as electron acceptor}

It is well established that the rate of the iron(III) reduction is microbially catalysed (Kostka \& Nelson 1995). Mineralogy, crystal structure, and surface area influence the availability of solid-phase iron(III) (Burdige 
Table 3. Stoichiometries for the microbiological reactions and the Gibbs Free energies for the reactions as written. $\Delta G_{f}^{0}=$ under standard conditions; $\Delta G_{f}$ for $\mathrm{pH}=7$. Reaction (4) uses hematite as iron(III) source and assumes that free aqueous iron(II) is released. All data are taken from CRC, 1988

\begin{tabular}{|c|c|c|c|c|}
\hline & & $\Delta G_{f}^{0}[\mathrm{~kJ}]$ & $\Delta G_{f}[\mathrm{~kJ}]$ & \\
\hline Oxygen reduction & $\mathrm{C}_{7} \mathrm{H}_{8}+9 \mathrm{O}_{2}+3 \mathrm{H}_{2} \mathrm{O} \rightarrow 7 \mathrm{H}_{2} \mathrm{CO}_{3}$ & -3798.9 & -3798.9 & (2) \\
\hline Iron(III) reduction & $\mathrm{C}_{7} \mathrm{H}_{8}+18 \mathrm{Fe}_{2} \mathrm{O}_{3}+72 \mathrm{H}^{+} \rightarrow 7 \mathrm{H}_{2} \mathrm{CO}_{3}+36 \mathrm{Fe}^{2+}+33 \mathrm{H}_{2} \mathrm{O}$ & -1500.3 & +1278.6 & (4) \\
\hline Sulfate reduction & $\mathrm{C}_{7} \mathrm{H}_{8}+4.5 \mathrm{SO}_{4}^{2-}+9 \mathrm{H}^{+}+3 \mathrm{H}_{2} \mathrm{O} \rightarrow 7 \mathrm{H}_{2} \mathrm{CO}_{3}+4.5 \mathrm{H}_{2} \mathrm{~S}$ & -573.8 & -226.4 & $(5)$ \\
\hline Methanogenesis from hydrogen & $10 \mathrm{H}_{2}+2.5 \mathrm{H}_{2} \mathrm{CO}_{3} \rightarrow 2.5 \mathrm{CH}_{4}+7.5 \mathrm{H}_{2} \mathrm{O}$ & -459.5 & -459.5 & $(8)$ \\
\hline
\end{tabular}

et al. 1992; Stumm \& Sulzberger 1992; Postma 1993). Ryan \& Gschwend (1991) suggest that the microbially accessible iron $\left(\mathrm{X}_{\mathrm{fe}_{2} \mathrm{O}_{3}}\right)$ can be measured by a reductive extraction with a $\mathrm{Ti}(\mathrm{III})$ solution. The $\mathrm{CBC}$ model assumes that all $\mathrm{Fe}$ (III) is equally accessible and can be utilized by the microorganisms from its solid form, which has a mol/L concentration as if it were a dissolved species.

\section{Fermentation stoichiometry}

The fermentative stoichiometry is characterised by two coefficients: the synthesis yield $Y_{a n}$ of the fermenting organisms and the yield of hydrogen per mole of converted substrate, $Y_{a n, \mathrm{H}_{2}}\left(\right.$ in $\mathrm{mol}_{\mathrm{H}_{2}} \mathrm{~mol}_{\mathrm{C}}^{-1}$ ). These two parameters determine, based on carbon and COD balances, the oxidation state of the average fermentation product, $i_{\mathrm{F}}$. Currently, no experimental data supply us with indisputable values for these coefficients. Based on the overall biomass yield of fermentative toluene degradation, we use $Y_{a n}=0.076 \operatorname{mol}_{C} \operatorname{mol}_{\mathrm{C}}^{-1}$. From a carbon and COD balance, we can calculate the coefficient $Y_{a n, \mathrm{H}_{2}}$ with:

$$
Y_{a n, \mathrm{H}_{2}}=\frac{-i_{\mathrm{F}} \cdot\left(1-Y_{a n}\right)+i_{\mathrm{HC}}-i_{\mathrm{XB}} Y_{a n}}{i_{\mathrm{H}_{2}}} .
$$

The $i$ coefficients can be found in Table 4. A reasonable assumption is that acetate is the final Cfermentation product of all possible fermentative processes (Maurer \& Rittmann 2004). From Table 4, we see that in this case $i_{\mathrm{F}}$ is $1.0 \mathrm{~mol}_{\mathrm{O}_{2}} \mathrm{~mol}_{\mathrm{C}}^{-1}$, giving $Y_{a n, \mathrm{H}_{2}}=0.502 \mathrm{~mol}_{\mathrm{H}_{2}} \operatorname{mol}_{\mathrm{C}}^{-1}$.

Similar considerations lead to the stoichiometric coefficient $\nu_{\mathrm{F}}$ for the stoichiometry of the fermentation product from BTEX fermentation:

$$
\nu_{\mathrm{F}}=\frac{i_{\mathrm{HC}}-Y_{a n, \mathrm{H}_{2}} \cdot i_{\mathrm{H}_{2}}-Y_{a n} \cdot i_{\mathrm{XB}}}{i_{\mathrm{F}} \cdot Y_{a n}} .
$$

\section{Methanogenesis stoichiometry}

Growth yields $\left(Y_{\mathrm{CH}_{1}}\right.$ and $\left.Y_{\mathrm{CH}_{2}}\right)$ for acetoclastic and hydrogen-oxidising methanogens can be found in the literature (e.g., Maillacheruvu \& Parkin 1996): $Y_{\mathrm{CH}_{1}}=0.09 \mathrm{~mol}_{\mathrm{C}} \mathrm{mol}_{\mathrm{C}}^{-1} ; Y_{\mathrm{CH}_{2}}=0.04 \mathrm{~mol}_{\mathrm{C}} \mathrm{mol}_{\mathrm{H}_{2}}^{-1}$.

\section{Oxidation of the fermentation product}

Acetate, the organic fermentation products $\left(\mathrm{S}_{\mathrm{F}}\right)$, is oxidized by oxygen-, nitrate-, and sulfate-reducing bacteria that degrade BTEX. Different are only the maximum growth rates and the half-saturation coefficients for acetate versus BTEX. The re-oxidation of the other reduced species are not considered in this model.

\section{Mass balances (coefficients $\sigma_{N}, \sigma_{C}, \sigma_{e-}$ )}

The stoichiometric coefficients $\sigma$ are gained from a mass balance, either for carbon $\left(\sigma_{\mathrm{C}}\right)$, nitrogen $\left(\sigma_{\mathrm{N}}\right)$, or charge $\left(\sigma_{e-}\right)$. They are calculated with the help of the coefficients in Table 2, in the last three rows labled MC, MN, and Me-, according to the following formulas:

$$
\sigma_{\mathrm{C}, \mathrm{a}, \mathrm{b}}=-\frac{1}{v_{\mathrm{MC}, \mathrm{b}}}\left(\sum_{i=1}^{b-1} v_{\mathrm{a}, \mathrm{i}}+\sum_{i=b+1}^{N} v_{\mathrm{a}, \mathrm{i}} \cdot v_{\mathrm{MC}, \mathrm{i}}\right)
$$

where $\sigma_{\mathrm{Ca}, \mathrm{b}}$ is the stoichiometric coefficient at row a and column $b$ based on a carbon mass balance; $a, b$ 
Table 4. COD of the CBC model compounds. [a]: Biomass $\mathrm{CH}_{2.09} \mathrm{O}_{0.54} \mathrm{~N}_{0.2}$ (Smolders et al. 1995)

\begin{tabular}{|c|c|c|}
\hline Compound & & $\mathrm{COD}(i) \operatorname{mol}_{\mathrm{O}_{2}} \mathrm{~mol}_{\mathrm{C}}^{-1}$ \\
\hline Benzene & $i_{\mathrm{HC}}$ & 1.25 \\
\hline Toluene & $i_{\mathrm{HC}}$ & 1.29 \\
\hline Ethylbenzene & $i_{\mathrm{HC}}$ & 1.31 \\
\hline Xylenes & $i_{\mathrm{HC}}$ & 1.31 \\
\hline Acteate & $i_{\mathrm{F}}$ & 1.00 \\
\hline Methane & $i_{\mathrm{CH}_{4}}$ & 2.00 \\
\hline Biomass $^{[\mathrm{a}]}$ & $i_{\mathrm{XB}}$ & 1.25 \\
\hline $\begin{array}{l}\text { Hydrogen } \\
\text { mol }_{\mathrm{O}_{2}} \mathrm{~mol}_{\mathrm{H}}^{-1}\end{array}$ & $i_{\mathrm{H}_{2}}$ & 0.5 \\
\hline
\end{tabular}

row \# and column \#; $\mathrm{N}$ is the total number of column; $v_{\mathrm{a}, \mathrm{I}}$ is the stoichiometric constant at row a and column $\mathrm{i}$ (in Table 2); $v_{\mathrm{MC}, \mathrm{I}}$ is the stoichiometric constant in mass balance row MC and column i (in Table 2).

Row MC, MN, and Me- are indicating the contribution of a state variable to the corresponding mass balance (for further details, see Larsen \& Gujer 1995). This procedure guarantees that no process violates any mass balance.

The model assumes that all biomass maintains a constant $\mathrm{N}: \mathrm{C}$ ratio. A typical value for $i_{\mathrm{N}, \mathrm{XB}}$ is 0.2 mol $_{\mathrm{N}} \mathrm{mol}_{\mathrm{C}}^{-1}$ (Smolders et al. 1995).

\section{Model module: Chemistry}

\section{Overview}

Integrating chemical reactions that affect the fate of biological footprints is at the heart of the CBC model. The key chemical reactions, relevant to freshwater conditions, were reviewed in Maurer \& Rittmann (2004) and are compiled in Table 5 and Table 6.

\section{Activity coefficients}

Although the reactions are relevant to freshwater, salt concentrations often are high enough to require activity corrections so that molar concentrations can be used in equilibrium expressions. To account for ionic strength $(0<I<0.1)$, we use the Güntelberg approximation (Stumm \& Morgan 1996):

$$
\log \left(f_{i}\right)=-0.5 \cdot i^{2} \cdot \frac{\sqrt{I}}{1+\sqrt{I}}
$$

$$
I=0.5 \cdot \sum_{j}\left(S_{j} \cdot z_{j}^{2}\right)
$$

where $S_{j}$ is the (measured) concentration of substance $j[\mathrm{M}], z_{j}$ is the charge of substance $j$, and $f_{i}$ is the activity coefficient for a ion with the charge $|i|$.

\section{Temperature correction}

The rate constants of the chemical reactions are corrected for the temperature according to the Arrhenius equation (Stumm \& Morgan 1996):

$$
k\left(T_{2}\right)=k\left(T_{1}\right) \cdot e^{-\frac{E_{a}}{R} \cdot\left(\frac{1}{T_{2}+273}-\frac{1}{T_{1}+273}\right)},
$$

where $k\left(T_{2}\right)$ and $k\left(T_{1}\right)$ are the rate constant at temperatures $T_{2}$, and $\mathrm{T}_{1}\left[{ }^{\circ} \mathrm{C}\right]$, respectively, $E_{a}$ is the activation energy coefficient of the reaction according to Arrhenius $\left[\mathrm{J} \mathrm{mol}^{-1}\right]$, and $R$ is the molar universal gas constant $\left(8.3144 \mathrm{~J} \mathrm{~mol}^{-1} \mathrm{~K}^{-1}\right)$.

Equilibrium constants are adapted to the ambient temperature with the van't Hoff relationship (Stumm \& Morgan 1996):

$$
\begin{aligned}
-\log \left(K\left(T_{K}\right)\right)= & \log (K(T=298 \mathrm{~K})) \\
& -\frac{\Delta H_{298}}{R \cdot \log (10)} \cdot\left(\frac{1}{298}-\frac{1}{T_{K}}\right)
\end{aligned}
$$

where $K$ is the equilibrium constant at $T_{K}$ or 298 [K], respectively, $\Delta H_{298}$ is the heat of formation at $298 \mathrm{~K}$ $\left[\mathrm{J} \mathrm{mol}{ }^{-1}\right]$, and $\mathrm{R}$ is the molar universal gas constant.

\section{Calcium carbonate (calcite)}

As discussed in Maurer \& Rittmann (2004), the net rate $\rho$ for the formation or dissolution of calcite $\left(\mathrm{CaCO}_{3, \mathrm{~s}}\right)$ close to the equilibrium $(1.2>\Omega>0.8)$ is given with:

$$
\begin{aligned}
\rho & =a_{\mathrm{CaCO}_{3}} \cdot k_{1} \cdot\left(1-\frac{f_{2} \mathrm{~S}_{\mathrm{Ca}} \cdot f_{2} \mathrm{~S}_{\mathrm{CO}_{3}}}{10^{-\mathrm{pKsp} 1}}\right)^{n} \\
& =a_{\mathrm{CaCO}_{3}} \cdot k_{1} \cdot\left(1-\Omega_{1}\right)^{n}
\end{aligned}
$$

where $\rho$ is the net reaction rate $\left[\mathrm{M} \mathrm{d}^{-1}\right], a_{\mathrm{CaCO}_{3}}$ the specific surface of calcite $\left[\mathrm{m}^{-2} \mathrm{lt}^{-1}\right], k_{1}$ the rate constant $\left[\mathrm{mol} \mathrm{m}{ }^{-2} \mathrm{~d}^{-1}\right], f_{2} \cdot S_{\mathrm{Ca}}$ and $f_{2} \cdot S_{\mathrm{CO}_{3}}$ are the activities of $\mathrm{Ca}^{2+}$, and $\mathrm{CO}_{3}^{2-}$ respectively [M], $\mathrm{pK}_{\mathrm{SP} 1}$ is the negative logarithm of the solubility constant of calcite $[-], n$ a constant, $\Omega_{1}$ is called the saturation 
Table 5. Stoichiometric matrix and the corresponding kinetics of the rate determined chemical reactions

\begin{tabular}{|c|c|c|c|c|c|c|c|c|c|c|c|c|c|}
\hline Process & $\begin{array}{l}\sum \\
\vdots \\
\infty \\
\omega \\
\text { S6 }\end{array}$ & 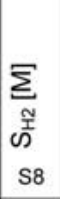 & 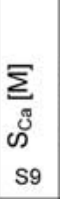 & 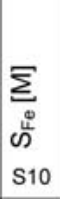 & $\begin{array}{l}\underset{\sum}{I} \\
\text { W } \\
\text { S11 }\end{array}$ & 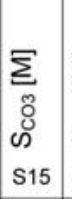 & 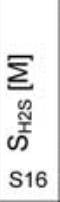 & 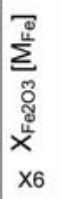 & 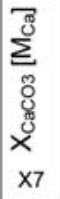 & 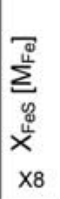 & 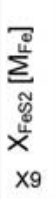 & $\begin{array}{l}\sum_{\infty}^{\infty} \\
x \\
x 10\end{array}$ & Process \\
\hline I1 Precipitation calcite & & & -1 & & & -1 & & & 1 & & & & $k_{1} \cdot a_{\mathrm{CaCO}_{3}} \cdot\left(1-\Omega_{1}\right)^{n}$ \\
\hline 12 Formation of pyrite & & 1 & & & & & -1 & & & -1 & 1 & & $k_{5} \cdot X_{F e S} \cdot S_{H 2 S}$ \\
\hline 13 Conversion to pyrite & & & & & & & & & & -1 & 1 & -1 & $k_{8} \cdot X_{F e S} \cdot X_{S}$ \\
\hline 14 Reductive dissolution & & & & 1 & -2 & & $-1 / 2$ & -1 & & & & $1 / 2$ & $a_{\mathrm{Fe} 2 \mathrm{O} 3} \cdot\left(k_{e 1} \cdot A_{\mathrm{FeS}}+k_{e 2} \cdot A_{\mathrm{FeSH}}\right)$ \\
\hline 14b Reductive dissolution & $\frac{1}{8}$ & & & 1 & $-\frac{14}{8}$ & & $-\frac{1}{8}$ & -1 & & & & & $a_{\mathrm{Fe} 203} \cdot\left(k_{e 1} \cdot A_{\mathrm{FeS}}+k_{e 2} \cdot A_{\mathrm{FeSH}}\right)$ \\
\hline
\end{tabular}

state, and $\left(1-\Omega_{1}\right)$ is the thermodynamic difference from equilibrium. Parameter values are listed in Appendix 2.

\section{Iron monosulfide (FeS)}

The formation of amorphous iron monosulfide from $\mathrm{Fe}^{2+}$ and sulfides is fast and treated as an equilibrium process, as reviewed in Maurer \& Rittmann (2004). The equation and the thermodynamic properties are given in Table 6.

\section{Formation of pyrite ( $\mathrm{FeS} 2$ ) from $\mathrm{FeS}$}

The rate of pyrite formation from amorphous iron sulfide (FeS) follows the findings of Rickard (1995, 1997; Rickard \& Luther 1997), as reviewed in Maurer \& Rittmann (2004). Amorphous FeS seems to be the main intermediate in natural aquatic environments, and its presence is a prerequisite for the formation of pyrite $\left(\mathrm{FeS}_{2}\right)$ by the following rate expression:

$$
\rho=k_{5} \cdot X_{\mathrm{FeS}} \cdot S_{\mathrm{H}_{2} \mathrm{~S}}
$$

where $\rho$ is the formation rate of pyrite $\left[\mathrm{M} \mathrm{d}^{-1}\right], X_{\mathrm{FeS}}$ is the concentration of iron sulfide, treated as if it were a dissolved species (mol $\mathrm{FeS}_{\mathrm{Fe}} \mathrm{l}_{\text {fluid }}^{-1}$ ) [M], $\mathrm{S}_{\mathrm{H}_{2} \mathrm{~S}}$ is the aqueous $\mathrm{H}_{2} \mathrm{~S}$ concentration [M], and $k_{5}$ is the rate constant $\left[\mathrm{M}^{-1} \mathrm{~d}^{-1}\right]$ at temperature $T$.

This formulation of the rate assumes that the ratio of iron monosulfide to total surface area is constant. This assumption is based on the observation that iron monosulfide $(\mathrm{FeS})$ is an intermediate that under natural conditions will not accumulate in large quantities (Davison 1991).
Because of its thermodynamic and kinetic stability, pyrite is assumed to be a final product, and therefore no dissolution reaction is considered (Maurer \& Rittmann 2004).

\section{Formation of pyrite $\left(\mathrm{FeS}_{2}\right)$ from elemental $\mathrm{S}$ and $\mathrm{FeS}$}

Various experiments document that elemental sulfur and iron monosulfide react together to form pyrite (Maurer \& Rittmann 2004). Elemental sulfur and iron monosulfide are products of the reductive dissolution of iron(III), described below. Little is known about the mechanisms and the reaction rates, although Rickard et al. (1995) report from a lab experiment that the reaction forms pyrite within days. The CBC-model uses simple first-order kinetics with respect of $\mathrm{X}_{\mathrm{FeS}}$ and $\mathrm{X}_{\mathrm{S}}$.

$$
\rho=k_{8} \cdot \mathrm{X}_{\mathrm{FeS}} \cdot \mathrm{X}_{\mathrm{S}}
$$

where $\rho$ is the formation rate of pyrite $\left[\mathrm{M} \mathrm{d}^{-1}\right], \mathrm{X}_{\mathrm{FeS}}$ is the concentration of iron monosulfide $[\mathrm{M}], \mathrm{X}_{\mathrm{S}}$ is the concentration of elemental sulfur $[\mathrm{M}]$, and $\mathrm{k}_{8}$ is the rate constant $\left[\mathrm{M}^{-1} \mathrm{~d}^{-1}\right]$ at temperature $\mathrm{T}$.

\section{Reductive dissolution of $\mathrm{Fe}(\mathrm{III})$}

The rate for the reductive dissolution of iron(III) derives from the approach developed by Dos Santos Afonso \& Stumm (1992). The rate of reductive dissolution is proportional to the concentration of the two surface complex $\equiv \mathrm{FeSH}\left(\mathrm{A}_{\mathrm{FeSH}}\right)$ and $\equiv \mathrm{FeS}^{-}\left(\mathrm{A}_{\mathrm{FeS}}\right)$ and is given in Table 5 (processes I4 and I4b). The concentration of the surface complexes can be derived from a set of equilibrium reactions under the assumption that the concentration of the surface complex $\equiv \mathrm{FeO}^{-}$can be neglected: 
Table 6. Reversible chemical reactions and thermodynamic equilibrium constants in the $\mathrm{CBC}$ model at $25^{\circ} \mathrm{C}$ and $\mathrm{I}=0$. Legend: $\log \mathrm{K}=\log$ of equilibrium constant at $298^{\circ} \mathrm{K} ; \Delta H_{298}=$ heat of formation at $298{ }^{\circ} \mathrm{K} ;{ }^{*}=$ sum of $\mathrm{H}_{2} \mathrm{CO}_{3}$, aq and $\mathrm{CO}_{2}$, aq ; References: b: Davison et al. (1999), d: Davison (1991), e: Stumm \& Morgan (1996), f: Plummer \& Busenberg (1982), Dos Santos Afonso \& Stumm (1992)

\begin{tabular}{|c|c|c|c|c|c|}
\hline Equation & $\log K$ & & Lit & $\Delta H_{298}\left(\mathrm{~J} \mathrm{~mol}^{-1}\right)$ & Lit \\
\hline $\begin{array}{l}\mathrm{H}_{2} \mathrm{O} \leftrightarrows \mathrm{OH}^{-}+\mathrm{H}^{+} \\
\mathrm{H}_{2} \mathrm{~S}_{(\mathrm{aq})} \leftrightarrows \mathrm{HS}^{-}+\mathrm{H}^{+} \\
\mathrm{H}_{2} \mathrm{CO}_{3}^{*} \leftrightarrows \mathrm{H}^{+}+\mathrm{HCO}_{3}^{-} \\
\mathrm{HCO}_{3}^{-} \leftrightarrows \mathrm{H}^{+}+\mathrm{CO}_{3}^{2-} \\
\mathrm{Fe}_{\mathrm{aq}}^{2+}+2 \mathrm{HS}^{-} \leftrightarrows \mathrm{Fe}(\mathrm{HS})_{2} \\
\mathrm{Fe}^{2+}+\mathrm{HCO}_{3}^{-} \leftrightarrows\left[\mathrm{FeHCO}_{3}\right]^{+} \\
\mathrm{Fe}^{2+}+\mathrm{CO}_{3}^{2-} \leftrightarrows\left[\mathrm{FeCO}_{3}\right]_{\mathrm{aq}}^{0} \\
\mathrm{Fe}^{2+}+\mathrm{CO}_{3}^{2-} \leftrightarrows\left[\mathrm{FeCO}_{3}\right]_{\mathrm{S}}^{0} \\
\mathrm{Fe}^{2+}+\mathrm{HS}^{-} \leftrightarrows \mathrm{H}^{+}+\left[\mathrm{FeS}_{\mathrm{S}, \text { amorph }}\right. \\
\mathrm{Ca}^{2+}+\mathrm{HCO}_{3}^{-} \leftrightarrows\left[\mathrm{CaHCO}_{3}\right]^{+} \\
\mathrm{Ca}^{2+}+\mathrm{CO}_{3}^{2-} \leftrightarrows\left[\mathrm{CaCO}_{3}\right]_{\mathrm{aq}}^{0}\end{array}$ & $\begin{array}{l}-14.0 \\
-6.98 \pm 0.02 \\
-6.36 \\
-10.33 \\
6.45 \pm 0.12 \\
2.0 \\
4.38 \\
10.45 \\
2.95 \\
2.69 \\
3.22\end{array}$ & & $\begin{array}{l}\mathrm{e} \\
\mathrm{d} \\
\mathrm{e} \\
\mathrm{e} \\
\mathrm{b} \\
\mathrm{e} \\
\mathrm{e} \\
\mathrm{e} \\
\mathrm{e} \\
\mathrm{e}\end{array}$ & $\begin{array}{r}9113 \\
14907\end{array}$ & $\begin{array}{l}\mathrm{e} \\
\mathrm{e}\end{array}$ \\
\hline 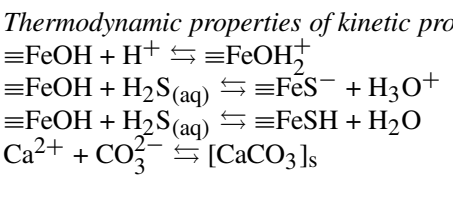 & $\begin{array}{r}\text { esses } \\
7.25 \\
-1.72 \\
3.80 \\
8.48\end{array}$ & $\begin{array}{l}-\mathrm{pK}_{\mathrm{A} 1} \\
-\mathrm{pK}_{\mathrm{A} 2} \\
-\mathrm{pKA} 3 \\
-\mathrm{pK} \mathrm{SP}_{\mathrm{SP}}\end{array}$ & $\begin{array}{l}\mathrm{g} \\
\mathrm{g} \\
\mathrm{g} \\
\mathrm{e}\end{array}$ & $\begin{array}{c}-3071.4 \\
9615\end{array}$ & $\begin{array}{l}\mathrm{f} \\
\mathrm{e}\end{array}$ \\
\hline
\end{tabular}

$$
\mathrm{A}_{\mathrm{FeS}}=\frac{\mathrm{A}_{\mathrm{FeSH}}}{\lambda} \cdot 10^{\mathrm{pKA} 3-\mathrm{pKA} 2+\mathrm{pH}}
$$

$\mathrm{A}_{\mathrm{FeSH}}=\mathrm{A}_{\mathrm{FeOH}, \mathrm{tot}}$

$$
\cdot\left(1+\xi+\frac{\xi}{\lambda} \cdot 10^{\mathrm{pKA} 3-\mathrm{pKA} 2+\mathrm{pH}}\right)^{-1}(20)
$$

$$
\begin{aligned}
\mathrm{A}_{\mathrm{FeOH}}= & \left(\mathrm{A}_{\mathrm{FeOH}, \mathrm{tot}}-\mathrm{A}_{\mathrm{FeSH}}-\mathrm{A}_{\mathrm{FeS}}\right) \cdot \lambda \\
& \frac{10^{-\mathrm{pH}-\mathrm{pKA} 1}}{1+\lambda \cdot 10^{-\mathrm{pH}-\mathrm{pKA} 1}}
\end{aligned}
$$

where all values for the thermodynamics and kinetics are taken from Dos Santos Afonso \& Stumm (1992) and are listed in Table 6. All other values are given in:

$$
\begin{gathered}
\xi=\frac{\mathrm{S}_{\mathrm{H}_{2} \mathrm{~S}} \cdot 10^{-\mathrm{pKA} 3}}{\left(1+\lambda \cdot 10^{-\mathrm{pKA} 1-\mathrm{pH}}\right)} \\
\lambda=e^{\frac{-F \cdot \psi}{R \cdot T_{K}}} \\
\psi=\frac{0.438 \cdot F}{\sqrt{I}} \cdot\left(\mathrm{A}_{\mathrm{FeOH}}-\mathrm{A}_{\mathrm{FeS}}\right)
\end{gathered}
$$

$\mathrm{A}_{\mathrm{FeS}}, \mathrm{A}_{\mathrm{FeSH}}$ and $\mathrm{A}_{\mathrm{FeOH}}$ are the concentration of the surface complexes $\equiv \mathrm{FeS}-, \equiv \mathrm{FeSH}$ and $\equiv \mathrm{FeOH}_{2}^{+}$, re-

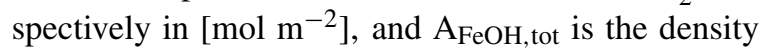
of sites on the iron-oxide surface. Table 5 presents two possible stoichiometries for the process: Elemental sulfur as the dominant product is described with $\mathrm{Fe}(\mathrm{OH})_{3}$ and $\mathrm{FeOOH}$ as iron minerals (process no. I4), whereas sulfate is the major product with hematite $\left(\mathrm{Fe}_{2} \mathrm{O}_{3}\right.$; process no. I4b).

\section{Equilibrium reactions}

The equilibrium reactions in Table 6 are needed to represent the chemical state of the aquatic environment. Because the subsurface environment normally is carbonate-buffered, it is possible to implement the equilibrium part of the CBC-model relatively simply. In particular, it is often possible to assume that the formation of carbonate complexes (e.g. $\left[\mathrm{FeHCO}_{3}\right]^{+}$, $\left[\mathrm{FeCO}_{3}\right]_{\mathrm{aq}}^{0},\left[\mathrm{CaHCO}_{3}\right]^{+},\left[\mathrm{CaCO}_{3}\right]_{\mathrm{aq}}^{0}$ ) does not influence the total carbonate concentration; therefore, the concentrations of free $\mathrm{Fe}^{2+}$ and $\mathrm{Ca}^{2+}$ and the $\mathrm{pH}$ can be computed analytically. This simplification needs to be evaluated for a specific case; however it usually is valid and avoids the need for solving the system of linear equations for the equilibrium reactions and makes the implementation of the model with a transport model (e.g., into RT3D, Clement 1997) tractable.

\section{Summary}

The CBC model contains novel features that allow it to comprehensively track the footprints of BTEX 
bioremediation, even when the fate of those footprints is confounded by abiotic reactions and complex interactions among different kinds of microorganisms. To achieve this comprehensive tracking of all the footprints, the $\mathrm{CBC}$ model contains important new biological features and key abiotic reactions.

The biological module of the CBC-model includes these important new aspects that are needed to track important footprints.

- The CBC model separates BTEX fermentation from methanogenesis. This introduces two fermentation products, acetate and hydrogen gas, both of which can be footprints. Frequently reported measurements of hydrogen and acetate in real sites and experiments indicate that fermentation occurs and therefore should be considered in a quantitative simulation model (Landmeyer et al. 1996; Cozzarelli et al. 1994; Chaudhuri \& Wiesmann 1996; Grbic-Galic \& Vogel 1987; Grbic-Galic 1991; Revesz et al. 1995).

- It explicitly include biomass as a sink for electrons and carbon. Ignoring synthesis as a sink for electrons can lead to significant overestimates of reduced products (such as sulfide and methane) and inorganic carbon.

- The CBC model has different growth rates for each biomass type. Due to the different growth rates of the several types of microorganisms, the various biodegradation pathways usually have significantly different startup times. This model feature corresponds well with laboratory experiments, which generally report long lag and startup phases, particularly for methanogenesis. For example Edwards \& Grbic-Galic (1991) observed anaerobic adaptation periods in chemostats of 100 to 120 days for toluene degradation and 200 to 255 days for o-xylene. Baedecker et al. (1993) reported that a plume from a crude oil spill became more reducing over a 5-year period.

- The model includes inhibition of the different reactions by other electron acceptors and by sulfide toxicants.

The chemical module of the CBC-model includes abiotic reactions that affect the footprints of the biological reactions. In particular, the chemical module describes the precipitation/dissolution of $\mathrm{CaCO}_{3}$, $\mathrm{Fe}_{2} \mathrm{O}_{3}, \mathrm{FeS}, \mathrm{FeS}_{2}$, and $\mathrm{S}^{\circ}$. The kinetics for the precipitation/dissolution reactions follow the critical review in Maurer \& Rittmann (2004). In addition, the CBC model includes equilibrium speciation of the carbonate and sulfide species, a feature necessary to describe the abiotic kinetics and inhibition of the biological reactions.

In conclusion, the $\mathrm{CBC}$ model explicitly couples the chemical and biological reactions needed to understand the fate of BTEX and its biodegradation footprints, even when the footprints are affected by other reactions. The CBC model makes it possible to evaluate the multiple biological and chemical processes that may affect the footprints from natural attenuation of BTEX. 


\section{Appendix 1 - Variables, symbols, and definitions}

\section{Program variables (state variables)}

\begin{tabular}{|c|c|c|c|}
\hline \multicolumn{4}{|c|}{ Dissolved components } \\
\hline \multicolumn{4}{|c|}{ Unit } \\
\hline $\mathrm{S}_{\mathrm{HC}}$ & S1 & $\mathrm{M}_{\mathrm{C}}$ & Hydrocarbons (BTEX) \\
\hline $\mathrm{S}_{\mathrm{F}}$ & $\mathrm{S} 2$ & M & Organic fermentation products \\
\hline $\mathrm{S}_{\mathrm{O}_{2}}$ & $\mathrm{~S} 3$ & M & Dissolved oxygen $\left(\mathrm{O}_{2, \mathrm{aq}}\right)$ \\
\hline $\mathrm{S}_{\mathrm{NO}}$ & S4 & M & $\begin{array}{l}\text { Nitrate }\left(\mathrm{NO}_{3}^{-}\right) \text {and nitrite } \\
\text { equivalents }\left(=0.6^{*} \mathrm{NO}_{2}^{-}\right)\end{array}$ \\
\hline $\mathrm{S}_{\mathrm{NH}}$ & S5 & M & Ammonium $\left(\mathrm{NH}_{4}^{+}\right)$ \\
\hline $\mathrm{S}_{\mathrm{SO}_{4}}$ & S6 & M & Sulfate $\left(\mathrm{SO}_{4}^{2-}\right)$ \\
\hline $\mathrm{S}_{\mathrm{CH}_{4}}$ & S7 & MC & Dissolved methane $\left(\mathrm{CH}_{4, \mathrm{aq}}\right)$ \\
\hline $\mathrm{S}_{\mathrm{H}_{2}}{ }^{4}$ & S8 & M & Dissolved hydrogen-gas $\left(\mathrm{H}_{2, \mathrm{aq}}\right)$ \\
\hline $\mathrm{S}_{\mathrm{Ca}}$ & S9 & M & Calcium $\left(\mathrm{Ca}^{2+}\right)$ \\
\hline $\mathrm{S}_{\mathrm{Fe}}$ & $\mathrm{S} 10$ & M & $\operatorname{Iron}(\mathrm{II})\left(\mathrm{Fe}_{\mathrm{aq}}^{2+}\right)$ \\
\hline $\mathrm{S}_{\mathrm{H}}$ & S11 & M & Proton-ion $\left(\mathrm{H}_{\mathrm{aq}}^{+}\right.$or $\left.\mathrm{H}_{3} \mathrm{O}^{+}\right)$ \\
\hline $\mathrm{S}_{\mathrm{OH}}$ & S12 & M & Hydroxyl-ion $\left(\mathrm{OH}^{-}\right)$ \\
\hline $\mathrm{S}_{\mathrm{H}_{2} \mathrm{CO}_{3}}$ & S13 & M & Dihydrogen carbonate $\left(\mathrm{H}_{2} \mathrm{CO}_{\mathrm{aq}}^{3 *}\right)$ \\
\hline $\mathrm{S}_{\mathrm{HCO}_{3}}$ & S14 & M & Hydrogen carbonate $\left(\mathrm{HCO}_{3}^{-}\right)$ \\
\hline $\mathrm{S}_{\mathrm{CO}_{3}}$ & S15 & M & Carbonate $\left(\mathrm{CO}_{3}^{2-}\right)$ \\
\hline $\mathrm{S}_{\mathrm{H}_{2} \mathrm{~S}}$ & S16 & M & Dihydrogen sulfide $\left(\mathrm{H}_{2} \mathrm{~S}_{\mathrm{aq}}\right)$ \\
\hline $\mathrm{S}_{\mathrm{HS}}$ & S17 & M & Hydrogen sulfide $\left(\mathrm{HS}^{-}\right)$ \\
\hline \multicolumn{4}{|c|}{ Dissolved Complexes } \\
\hline $\mathrm{S}_{\mathrm{CaCO}_{3}}$ & S18 & M & Calcium carbonate $\left(\mathrm{CaCO}_{3, \mathrm{aq}}\right)$ \\
\hline $\mathrm{S}_{\mathrm{CaHCO}_{3}}$ & S19 & $\mathrm{M}$ & $\begin{array}{l}\text { Calcium hydrogen carbonate } \\
\left(\mathrm{CaHCO}_{3, \mathrm{aq}}^{+}\right)\end{array}$ \\
\hline $\mathrm{S}_{\mathrm{FeCO}_{3}}$ & S20 & M & Iron(II) carbonate $\left(\mathrm{FeCO}_{3, \mathrm{aq}}\right)$ \\
\hline $\mathrm{S}_{\mathrm{FeHCO}_{3}}$ & $\mathrm{~S} 21$ & $\mathrm{M}$ & $\begin{array}{l}\text { Iron(II) hydrogen carbonate } \\
\left(\mathrm{FeHCO}_{3, a q}^{+}\right)\end{array}$ \\
\hline $\mathrm{S}_{\mathrm{FeHS}_{2}}$ & S22 & M & $\begin{array}{l}\text { Iron(II) dihydrogen sulfide } \\
\left(\mathrm{Fe}(\mathrm{HS})_{2, \mathrm{aq}}\right)\end{array}$ \\
\hline
\end{tabular}

\begin{tabular}{|c|c|c|c|}
\hline \multicolumn{4}{|c|}{ Particulate components } \\
\hline $\mathrm{X}_{\mathrm{BO}}$ & $\mathrm{X} 1$ & $\mathrm{M}_{\mathrm{C}}$ & $\begin{array}{l}\text { Het. biomass using oxygen and } \\
\text { nitrate as electron acceptors }\end{array}$ \\
\hline $\mathrm{X}_{\mathrm{BF}}$ & $\mathrm{X} 2$ & $\mathrm{M}_{\mathrm{C}}$ & $\begin{array}{l}\text { Het. biomass using iron(III) as } \\
\text { electron acceptors }\end{array}$ \\
\hline $\mathrm{X}_{\mathrm{BS}}$ & $\mathrm{X} 3$ & $\mathrm{M}_{\mathrm{C}}$ & $\begin{array}{l}\text { Het. biomass using sulfate as } \\
\text { electron acceptors }\end{array}$ \\
\hline $\mathrm{X}_{\mathrm{BAc}}$ & $\mathrm{X} 4$ & $\mathrm{M}_{\mathrm{C}}$ & $\begin{array}{l}\text { Methanogenic biomass (splitting } \\
\text { acetate) }\end{array}$ \\
\hline $\mathrm{X}_{\mathrm{BH}_{2}}$ & $\mathrm{X} 5$ & $\mathrm{MC}$ & $\begin{array}{l}\text { Methanogenic biomass (using } \\
\text { hydrogen) }\end{array}$ \\
\hline $\mathrm{X}_{\mathrm{Fe}_{2} \mathrm{O}_{3}}$ & $\mathrm{X} 6$ & $\mathrm{M}_{\mathrm{Fe}}$ & Iron(III)oxide \\
\hline $\mathrm{X}_{\mathrm{CaCO}_{3}}$ & $\mathrm{X} 7$ & $\mathrm{M}_{\mathrm{C}}$ & Calcium carbonate (calcite, $\mathrm{CaCO}_{3}$ ) \\
\hline $\mathrm{X}_{\mathrm{FeS}}$ & $\mathrm{X} 8$ & $\mathrm{M}_{\mathrm{Fe}}$ & Iron monosulfide (FeS $\left.\mathrm{S}_{\text {amorph }}\right)$ \\
\hline $\mathrm{X}_{\mathrm{FeS}_{2}}$ & X9 & $\mathrm{M}_{\mathrm{Fe}}$ & Pyrit $\left(\mathrm{FeS}_{2}\right)$ \\
\hline $\mathrm{X}_{\mathrm{S}}$ & $\mathrm{X} 10$ & $\mathrm{M}_{\mathrm{S}}$ & Elementary sulfur $\left(\mathrm{S}_{8}\right)$ \\
\hline
\end{tabular}

General parameters

$\begin{array}{llll} & \text { Units } & \text { Value } & \text { Remark } \\ \mathrm{F} & \mathrm{C} \mathrm{mol}^{-1} & 96484.6 & \text { Faraday constant } \\ f_{i} & - & \text { see eq. (12) } & \text { Activity coefficient } \\ \mathrm{I} & - & \text { see eq. (13) } & \text { Ionic strength } \\ \mathrm{pH} & - & -\log (\mathrm{SH}) & \text { pH definition } \\ \mathrm{R} & \mathrm{J} \mathrm{mol}^{-1} \mathrm{~K}^{-1} & 8.3144 & \text { Molar gas constant } \\ \mathrm{T} & { }^{\circ} \mathrm{C} & & \text { Temperature in }{ }^{\circ} \mathrm{C} \\ \mathrm{T}_{\mathrm{K}} & \mathrm{K} & & \text { Temperature in } \mathrm{K}\end{array}$

\section{Appendix 2. Standard values of stoichiometric and kinetic parameters}

\section{Stoichiometric parameters}

\begin{tabular}{|c|c|c|c|c|}
\hline Param. & Value & Unit & Lit & Description, remarks \\
\hline$v_{\mathrm{F}}$ & 12.16 & - & $\{\mathrm{t}\}$ & Stoichiometric coefficient for the production of fermentation products (see eq. (10)) \\
\hline$v_{\mathrm{i}}$ & 0.02 & - & $\{1\}$ & Fraction of inert Carbon after decay of biomass \\
\hline$f_{\text {nh }}$ & & - & & $\begin{array}{l}\text { Description: distribution factor for the use of nitrate or ammonium as N-source. } \\
\mathrm{f}_{\mathrm{nh}}=\mathrm{S}_{\mathrm{NH}} /\left(\mathrm{K}_{\mathrm{N}}+\mathrm{S}_{\mathrm{NH}}\right)\end{array}$ \\
\hline $\mathrm{i}_{\mathrm{CH}_{4}}$ & 2.0 & molo $_{2} \operatorname{mol}_{\mathrm{C}}^{-1}$ & $\{t\}$ & COD of methane \\
\hline$i_{f}$ & 1.0 & $\mathrm{~mol}_{\mathrm{O}_{2}} \mathrm{~mol}_{\mathrm{C}}^{-1}$ & $\{t\}$ & COD of SF, if assumed to be acetate only \\
\hline $\mathrm{i}_{\mathrm{H}_{2}}$ & 0.5 & $\mathrm{~mol}_{\mathrm{O} 2} \mathrm{~mol}_{\mathrm{H}_{2}^{-1}}$ & $\{\mathrm{t}\}$ & COD of hydrogen \\
\hline$i_{\mathrm{HC}}$ & 1.27 & $\mathrm{~mol}_{\mathrm{O} 2} \mathrm{~mol}_{\mathrm{C}}^{-1}$ & $\{\mathrm{t}\}$ & COD of BTEX (hydrocarbons); see Table 4 \\
\hline $\mathrm{i}_{\mathrm{N}, \mathrm{XB}}$ & 0.2 & $\mathrm{~mol}_{\mathrm{N}} \operatorname{mol}_{\mathrm{C}}^{-1}$ & $\{2\}$ & Nitrogen content of biomass \\
\hline$i_{X B}$ & 1.25 & $\mathrm{~mol}_{\mathrm{O}_{2}} \mathrm{~mol}_{\mathrm{C}}^{-1}$ & $\{2\}$ & COD of biomass \\
\hline$Y_{\text {an }}$ & 0.076 & $\operatorname{mol}_{\mathrm{C}} \mathrm{mol}_{\mathrm{C}}^{-1}$ & $\{5\}$ & Growth yield of heterotrophic organisms on fermentation \\
\hline $\mathrm{Y}_{\mathrm{an}, \mathrm{H}_{2}}$ & 0.502 & $\mathrm{~mol}_{\mathrm{H}_{2}} \mathrm{~mol}_{\mathrm{C}}^{-1}$ & $\{\mathrm{~T}\}$ & $\begin{array}{l}\text { Hydrogen production in anaerobic fermentation (mole hydrogen per mole of } \\
\text { substrate); see eq. (9) }\end{array}$ \\
\hline
\end{tabular}




\begin{tabular}{lllll}
\hline Param. & Value & Unit & Lit & Description, remarks \\
\hline $\mathrm{Y}_{\mathrm{Fe}}$ & 0.07 & $\mathrm{~mol}_{\mathrm{C}} \mathrm{mol}_{\mathrm{C}}^{-1}$ & $\{\mathrm{~T}\}$ & Growth yield of heterotrophic organisms using Fe(III) \\
$\mathrm{Y}_{\mathrm{CH}_{1}}$ & 0.09 & $\mathrm{~mol}_{\mathrm{C}} \mathrm{mol}_{\mathrm{C}}^{-1}$ & $\{3\}\{6\}$ & Growth yield of acetoclastic methanogens \\
$\mathrm{Y}_{\mathrm{CH}_{2}}$ & 0.044 & $\mathrm{~mol}_{\mathrm{C}} \mathrm{mol}_{\mathrm{H}}^{-1}$ & $\{3\}\{6\}$ & Growth yield of hydrogen oxidising methanogens \\
$\mathrm{Y}_{\mathrm{NO}}$ & $0.8 \cdot \mathrm{Y}_{\mathrm{O}}$ & $\mathrm{mol}_{\mathrm{C}} \mathrm{mol}_{\mathrm{C}}^{-1}$ & $\{\mathrm{~T}\}$ & Growth yield of heterotrophic organisms using nitrate as electron acceptor \\
$\mathrm{Y}_{\mathrm{O}}$ & 0.51 & $\mathrm{~mol}_{\mathrm{C}} \mathrm{mol}_{\mathrm{C}}^{-1}$ & $\{14\}$ & $\begin{array}{l}\text { Growth yield of heterotrophic organisms using oxygen as electron acceptor. } \\
\text { Averaged value from 9 different pure culture studies with benzene and toluene }\end{array}$ \\
& & & & and converted with a molecular weight for biomass of 26 $\mathrm{g}_{\text {mol }}^{-1}$. \\
$\mathrm{Y}_{\mathrm{SO}}$ & $0.13 \cdot \mathrm{Y}_{\mathrm{O}}$ & $\mathrm{mol}_{\mathrm{C}} \mathrm{mol}_{\mathrm{C}}^{-1}$ & $\{\mathrm{~T}\}$ & Growth yield of heterotrophic organisms using sulfate as electron acceptor \\
\hline
\end{tabular}

Kinetic parameters

\begin{tabular}{|c|c|c|c|c|}
\hline Param. & Value & Unit & Lit & Description, remarks \\
\hline$\eta_{\text {an }}$ & 0.1 & - & $\{7\}$ & Reduction coefficient for the fermentative max. growth rate \\
\hline$\eta_{\text {no }}$ & 0.8 & - & $\{8\}$ & Reduction coefficient for the anoxic max. growth rate \\
\hline$\mu_{\mathrm{Ac}, 25}$ & 0.09 & $d^{-1}$ & $\{6\}$ & Growth rate constant of acetoclastic organisms at $25^{\circ} \mathrm{C}$ \\
\hline$\mu_{\mathrm{Fe}, 25}$ & 0.08 & $d^{-1}$ & $\{t\}$ & Heterotrophic growth rate constant growing on iron(III) at $25^{\circ} \mathrm{C}$ \\
\hline$\mu_{\mathrm{Fe}, \mathrm{F}, 25}$ & 0.1 & $d^{-1}$ & $\{t\}$ & Heterotrophic growth rate constant with acetate at $25^{\circ} \mathrm{C}$ for iron(III) \\
\hline$\mu_{\mathrm{H}_{2}, 25}$ & 0.8 & $d^{-1}$ & $\{6\}$ & Growth rate constant of methanogens at $25^{\circ} \mathrm{C}$ \\
\hline$\mu_{\mathrm{O}, 25}$ & 0.16 & $d^{-1}$ & $\{4\}$ & Heterotrophic growth rate constant growing on oxygen at $25^{\circ} \mathrm{C}$ \\
\hline$\mu_{\mathrm{O}, \mathrm{F}, 25}$ & 6.0 & $d^{-1}$ & $\{7\}$ & Aerobic heterotrophic growth rate constant with acetate at $25^{\circ} \mathrm{C}$ \\
\hline$\mu_{\mathrm{SO}, 25}$ & 0.08 & $d^{-1}$ & $\{t\}$ & Heterotrophic growth rate constant growing on sulfate at $25^{\circ} \mathrm{C}$ \\
\hline$\mu_{\mathrm{SO}, \mathrm{F}, 25}$ & 0.1 & $d^{-1}$ & $\{t\}$ & Heterotrophic growth rate constant with acetate at $25^{\circ} \mathrm{C}$ for sulfate \\
\hline$\lambda_{\text {rfe }}$ & 0.069 & ${ }^{\circ} \mathrm{C}^{-1}$ & $\{t\}$ & Temperature coefficient for $\mathrm{r}_{\mathrm{Fe}}$ (growth on iron(III)) \\
\hline$\lambda_{\mathrm{rCH}_{1}}$ & 0.069 & ${ }^{\circ} \mathrm{C}^{-1}$ & $\{t\}$ & Temperature coefficient for $\mathrm{r}_{\mathrm{CH} 1}$ (methanogenesis by cleavage of acetate) \\
\hline$\lambda_{\mathrm{rCH}_{2}}$ & 0.069 & ${ }^{\circ} \mathrm{C}^{-1}$ & $\{t\}$ & Temperature coefficient for $\mathrm{r}_{\mathrm{CH} 2}$ (methanogenesis by cleavage of acetate) \\
\hline$\lambda_{\mathrm{rO}}$ & 0.069 & ${ }^{\circ} \mathrm{C}^{-1}$ & $\{t\}$ & Temperature coefficient for $\mathrm{r}_{\mathrm{O}}$ (aerobic growth) \\
\hline$\lambda_{\mathrm{rSO}}$ & 0.069 & ${ }^{\circ} \mathrm{C}^{-1}$ & $\{t\}$ & Temperature coefficient for rSO $_{\text {(growth on sulfate) }}$ \\
\hline$\Omega_{1}$ & & - & $\{\mathrm{T}\}$ & Saturation state of calcite, see eq. (16) \\
\hline $\mathrm{A}_{\mathrm{FeOH}, \mathrm{tot}}$ & $1.66 \cdot 10^{-6}$ & $\mathrm{~mol} \mathrm{~m}^{-2}$ & $\{11\}$ & Density of total active sites on a $\mathrm{X}_{\mathrm{Fe}_{2} \mathrm{O}_{3}}$ surface, typically: $10^{18}$ sites per $\mathrm{m}^{2}$ \\
\hline $\mathrm{A}_{\mathrm{FeS}}$ & & $\mathrm{mol} \mathrm{m}^{-2}$ & $\{11\}$ & Concentration of surface complex $\equiv \mathrm{FeS}^{-}$(see eq. (19)) \\
\hline $\mathrm{A}_{\mathrm{FeSH}}$ & & $\mathrm{mol} \mathrm{m}^{-2}$ & $\{11\}$ & Concentration of surface complex $\mathrm{A}_{\mathrm{FeSH}}$ (see eq. (20)) \\
\hline $\mathrm{a}_{\mathrm{Fe}_{2} \mathrm{O}_{3}}$ & & $\mathrm{M}^{2} \mathrm{lt}^{-1}$ & & Specific surface area of $\mathrm{X}_{\mathrm{Fe}_{2} \mathrm{O}_{3}}$ \\
\hline $\mathrm{a}_{\mathrm{CaCO} 3}$ & & $\mathrm{M}^{2} \mathrm{lt}^{-1}$ & & Specific surface area of $\mathrm{X}_{\mathrm{CaCO}_{3}}$ \\
\hline $\mathrm{b}_{\mathrm{BAc}, 25}$ & $0.15 \cdot \mathrm{r}_{\mathrm{CH}_{1}, 25}$ & $\mathrm{~d}^{-1}$ & $\{3\}\{6\}$ & Lysis rate constant for $\mathrm{X}_{\mathrm{BAc}}$ at $25^{\circ} \mathrm{C}$ \\
\hline $\mathrm{b}_{\mathrm{BFe}, 25}$ & $0.1 \cdot \mathrm{r}_{\mathrm{Fe}, 25}$ & $d^{-1}$ & $\{t\}$ & Lysis rate constant for $\mathrm{X}_{\mathrm{BF}}$ at $25^{c} i r c \mathrm{C}$ \\
\hline $\mathrm{b}_{\mathrm{BH}_{2}, 25}$ & $0.15 \cdot \mathrm{r}_{\mathrm{CH}_{2}, 25}$ & $d^{-1}$ & $\{3\}\{6\}$ & Lysis rate constant for $\mathrm{XBH} 2$ at $25^{\circ} \mathrm{C}$ \\
\hline $\mathrm{b}_{\mathrm{BO}, 25}$ & $0.1 \cdot \mathrm{r}_{\mathrm{O}, 25}$ & $\mathrm{~d}^{-1}$ & $\{\mathrm{t}\}$ & Lysis rate constant for $\mathrm{XBO}$ at $25^{\circ} \mathrm{C}$ \\
\hline $\mathrm{b}_{\mathrm{BSO}, 25}$ & $0.1 \cdot \mathrm{r}_{\mathrm{SO}, 25}$ & $\mathrm{~d}^{-1}$ & $\{t\}$ & Lysis rate constant for $\mathrm{X}_{\mathrm{BSO}}$ at $25^{\circ} \mathrm{C}$ \\
\hline $\mathrm{E}_{\mathrm{a}, \mathrm{k} 1}$ & 45500 & $\mathrm{~J} \mathrm{~mol}^{-1}$ & $\{9\}$ & Arrhenius 'Activation energy' for calcite formation \\
\hline $\mathrm{E}_{\mathrm{a}, \mathrm{k} 5}$ & 35000 & $\mathrm{~J} \mathrm{~mol}^{-1}$ & $\{10\}$ & 'Activation energy' for $\mathrm{FeS} 2$ formation \\
\hline $\mathrm{E}_{\mathrm{a}, \mathrm{k} 8}$ & 47787 & $\mathrm{~J} \mathrm{~mol}^{-1}$ & $\{t\}$ & 'Activation energy; for $\mathrm{FeS}+\mathrm{S}$ conversion (283-293 K = factor 2) \\
\hline $\mathrm{k}_{1,25}$ & 0.156 & $\mathrm{~mol} \mathrm{~m}^{-2} \mathrm{~d}^{-1}$ & $\{12\}$ & Reaction rate constant for precipitation of calcite at $25^{\circ} \mathrm{C}$ \\
\hline $\mathrm{k}_{5,25}$ & 8.90 & $\mathrm{M}^{-1} \mathrm{~d}^{-1}$ & $\{10\}$ & Reaction rate constant for precipitation of $\mathrm{FeS}_{2}$ at $25^{\circ} \mathrm{C}$ \\
\hline $\mathrm{k}_{8,25}$ & 0.01 & $M^{-1} d^{-1}$ & $\{t\}$ & Reaction rate constant for conversion of $\mathrm{FeS}$ and $\mathrm{S}$ to $\mathrm{FeS}_{2}$ \\
\hline $\mathrm{k}_{\mathrm{e} 1,25}$ & 720 & $d^{-1}$ & $\{11\}$ & Reaction rate constant for the reductive dissolution of $\mathrm{X}_{\mathrm{Fe}_{2} \mathrm{O}_{3}}$ at $25^{\circ} \mathrm{C}$ \\
\hline $\mathrm{k}_{\mathrm{e} 2,25}$ & 9600 & $d^{-1}$ & $\{11\}$ & Reaction rate constant for the reductive dissolution of $\mathrm{Xfe}_{2} \mathrm{O}_{3}$ at $25^{\circ} \mathrm{C}$ \\
\hline
\end{tabular}




\begin{tabular}{|c|c|c|c|c|}
\hline Param. & Value & Unit & Lit & Description, remarks \\
\hline $\mathrm{K}_{\mathrm{F} 1}$ & $230 \cdot 10^{-6}$ & $\mathrm{~mol}_{\mathrm{C}} \mathrm{lt}^{-1}$ & $\{13\}$ & Half saturation coefficient for acetate and acetoclastic organisms (B11) \\
\hline $\mathrm{K}_{\mathrm{F}}$ & $10^{-5}$ & $\operatorname{mol}_{C} \mathrm{lt}^{-1}$ & $\{t\}$ & Half saturation coefficient for fermentation products \\
\hline $\mathrm{K}_{\mathrm{Fe}_{2} \mathrm{O}_{3}}$ & $10^{-3}$ & $\mathrm{~mol}_{\mathrm{C}} \mathrm{mol}_{\mathrm{Fe}}^{-1}$ & $\{t\}$ & Half saturation coefficient for iron(III) $\left(\mathrm{Xfe}_{2} \mathrm{O}_{3}\right)$ \\
\hline $\mathrm{K}_{\mathrm{H}_{2}}$ & $0.15 \cdot 10^{-6}$ & $\operatorname{mol}_{H_{2}} 1 t^{-1}$ & $\{3\}$ & Half saturation coefficient for hydrogen utilisation of methanogens \\
\hline $\mathrm{K}_{\mathrm{H} 2 \text {, an }}$ & $5 \cdot 10^{-6}$ & $\mathrm{~mol}_{\mathrm{H}_{2}} 1 \mathrm{t}^{-1}$ & $\{t\}$ & Inhibition coefficient for hydrogen and fermentation \\
\hline $\mathrm{K}_{\mathrm{HC}}$ & $0.25 \cdot 10^{-6}$ & $\operatorname{mol}_{C}{ }^{-1} t^{-1}$ & $\{4\}$ & Half saturation coefficient for BTEX; $\mathrm{K}_{\text {Benzene }}=0.2 \mu \mathrm{M}_{\mathrm{C}} ; \mathrm{K}_{\mathrm{TEX}}=0.3 \mu \mathrm{M}_{\mathrm{C}}$ \\
\hline $\mathrm{K}_{\mathrm{IS} 1}$ & $3.4 \cdot 10^{-3}$ & $\mathrm{~mol}_{S} 1 \mathrm{t}^{-1}$ & $\{3\}$ & Inhibition coefficient for sulfide $\left(\mathrm{H}_{2} \mathrm{~S}\right)$ of acetoclastic methanogens \\
\hline $\mathrm{K}_{\mathrm{IS} 2}$ & $19.5 \cdot 10^{-3}$ & $\mathrm{~mol}_{S} \mathrm{lt}^{-1}$ & $\{3\}$ & Inhibition coefficient for sulfide $\left(\mathrm{H}_{2} \mathrm{~S}\right)$ of hydrogenotrophic methanogens \\
\hline $\mathrm{K}_{\mathrm{IS} 3}$ & $1.1 \cdot 10^{-3}$ & $\mathrm{~mol}_{\mathrm{S}} \mathrm{l}^{-1}$ & $\{3\}$ & Inhibition coefficient for sulfide $\left(\mathrm{HS}^{-}+\mathrm{H}_{2} \mathrm{~S}\right)$ of acetate $\mathrm{SBR}\left(35 \mathrm{mg} / \mathrm{l} \mathrm{S}_{\mathrm{tot}}\right)$ \\
\hline $\mathrm{K}_{\mathrm{IS} 4}$ & $21.2 \cdot 10^{-3}$ & $\mathrm{~mol}_{S} 1 \mathrm{t}^{-1}$ & $\{3\}$ & Inhibition coefficient for sulfide $\left(\mathrm{HS}^{-}+\mathrm{H}_{2} \mathrm{~S}\right)$ of $\mathrm{SBR}$ \\
\hline $\mathrm{K}_{\mathrm{IS} 5}$ & $1.0 \cdot 10^{-3}$ & $\mathrm{~mol}_{S} 1 \mathrm{t}^{-1}$ & $\{3\}$ & Inhibition coefficient for sulfide $\left(\mathrm{H}_{2} \mathrm{~S}\right)$ of fermentation \\
\hline $\mathrm{K}_{\mathrm{N}}$ & $5.0 \cdot 10^{-6}$ & $\mathrm{~mol}_{\mathrm{N}} \mathrm{lt}^{-1}$ & $\{t\}$ & Half saturation coefficient for nitrogen and biomass growth \\
\hline $\mathrm{K}_{\mathrm{NO}}$ & $3.0 \cdot 10^{-6}$ & $\operatorname{mol}_{N} 1 t^{-1}$ & $\{t\}$ & Half saturation coefficient for nitrate \\
\hline $\mathrm{K}_{\mathrm{O}}$ & $3.0 \cdot 10^{-6}$ & $\operatorname{mol}_{\mathrm{O}_{2}} 1 \mathrm{t}^{-1}$ & $\{t\}$ & Half saturation coefficient for oxygen \\
\hline $\mathrm{K}_{\mathrm{SO}}$ & $1.0 \cdot 10^{-6}$ & $\operatorname{mol}_{S} \mathrm{lt}^{-1}$ & $\{\mathrm{t}\}$ & Half saturation coefficient for sulfate \\
\hline $\mathrm{n}$ & 3.3 & - & $\{12\}$ & $\begin{array}{l}\text { Exponential factor for the calcite dissolution rate and conditions close to the } \\
\text { equilibrium }\left(1.2>\Omega_{1}>0.8\right) \text {, see eq. (16) }\end{array}$ \\
\hline $\mathrm{pK}_{\mathrm{A} 1}$ & 7.25 & - & $\{\mathrm{T}\}$ & Equilibrium constant for $\equiv \mathrm{FeOH}_{2}^{+}$, see Table 6 \\
\hline $\mathrm{pK}_{\mathrm{A} 2}$ & -1.72 & - & $\{\mathrm{T}\}$ & Solubility product of $\equiv \mathrm{FeS}^{-}$, see Table 6 \\
\hline $\mathrm{pK}_{\mathrm{A} 3}$ & 3.80 & - & $\{\mathrm{T}\}$ & Solubilty product of $\equiv \mathrm{FeSH}$, see Table 6 \\
\hline $\mathrm{pK}_{\mathrm{SP} 1}$ & 8.48 & - & $\{\mathrm{T}\}$ & Solubility product of calcite, see Table 6 \\
\hline
\end{tabular}

Legend: $\{\mathrm{t}\}$ : typical value, $\{\mathrm{T}\}$ : see text, $\{1\}$ : Rittmann et al. (1987), \{2\}: Smolders et al. (1995), \{3\}: Maillacheruvu \& Parkin (1996), $\{4\}$ : Bielefeld \& Stensel (1999), \{5\}: Schink (1997); Thauer et al. (1977), \{6\}: Gujer \& Zehnder (1983) and Zehnder et al. (1982), \{7\}: Henze et al. (2000), \{8\}: Kuba et al. (1996), \{9\}: Dawe \& Zhang (1997); White (1997); Kralj \& Brecevic (1995); Kralj et al. (1997), \{10\}: Rickard (1997), \{11\}: Dos Santos Afonso \& Stumm (1992), \{12\}: Svensson \& Dreybrodt (1992), \{13\}: Smith \& Mah (1980), \{14\}: Reardon et al. (2000).

\section{References}

Bae W \& Rittmann BE (1996) A structured model of dual-limitation kinetics. Biotechnol. Bioengr. 49: 683-689

Baedecker MJ, Cozzarelli IM, Eganhouse RP, Siegel DI \& Bennett PC (1993) Crude-oil in a shallow sand and gravel aquifer. 3. Biogeochemical reactions and mass-balance modeling in anoxic groundwater. Appl. Geochem. 8(6): 569-586

Bielefeldt AR \& Stensel HD (1999a) Evaluation of biodegradation kinetic testing methods and longterm variability in biokinetics for BTEX metabolism. Water Res. 33: 733-740

Burdige DJ, Dhakar SP \& Nealson KH (1992) Effects of manganese oxide mineralogy on microbial and chemical manganese reduction. Geomicrobiol. J. 10(1): 27-48

Chaudhuri BK \& Wiesmann U (1996) Kinetic study of the anaerobic degradation of toluene by a mixed culture. Acta Biotechnol. 16: 31-41

Clement TP (1997) Rt3d - a modular computer code for simulating reactive multi-species transport in 3-dimensional groundwater systems. The U.S. Department of Energy, PNNL-SA-11720, Contract DE-AC06-76RLO 1830

Cozzarelli IM, Baedecker MJ, Eganhouse RP \& Goerlitz DF (1994) The geochemical evolution of low-molecular-weight organic-acids derived from the degradation of petroleum con- taminants in groundwater. Geochim. Cosmochim. Acta 58: 863-877.

Davison W (1991) The solubility of iron sulfides in synthetic and natural-waters at ambient-temperature. Aquat. Sci. 53: 309-329

Davison W, Phillips N \& Tabner BJ (1999) Soluble iron sulfide species in natural waters: Reappraisal of their stoichiometry and stability constants. Aquat. Sci. 61(1): 23-43

Dawe RA \& Zhang YP (1997) Kinetics of calcium carbonate scaling using observations from glass micromodels. J. Petrol. Sci. Eng. 18: 179-187

Dos Santos Afonso MD \& Stumm W (1992) Reductive dissolution of Iron(III) (hydr)oxides by hydrogen-sulfide. Langmuir 8: 1671-1675

Edwards EA \& Grbicgalic D (1994) Anaerobic degradation of toluene and o-xylene by a methanogenic consortium. Appl. Environ. Microbiol. 60: 313-322

Grbicgalic D (1991) Anaerobic transformation of aromatic hydrocarbon pollutants under fermentative methanogenic conditions. Period. Biol. 93: 533-546

Grbicgalic D \& Vogel TM (1987) Transformation of toluene and benzene by mixed methanogenic cultures. Appl. Environ. Microbiol. 53: 254-260

Gujer W \& Zehnder AJB (1983) Conversion processes in anaerobic digestion. Water Sci. Technol. 15: 127-67 
Henze M, Gujer W, Mino T \& VanLoosdrecht M (2000) Activated sludge models ASM1, ASM2, ASM2d and ASM3. IAWQ Scientific and Technical Reports, No. 9, IAWQ, London, ISBN 1900222248

Kostka JE, Dalton DD, Skelton H, Dollhopf S \& Stucki JW (2002) Growth of iron(III)-reducing bacteria on clay minerals as the sole electron acceptor and comparison of growth yields on a variety of oxidized iron forms. Appl. Environ. Microbiol. 68(12): 62566262

Kostka JE \& Nealson KH (1995) Dissolution and reduction of magnetite by bacteria. Environ. Sci. Technol. 29: 2535-2540

Kralj D \& Brecevic L (1995) Dissolution kinetics and solubility of calcium-carbonate monohydrate. Colloid. Surface. A. 96: 287293

Kralj D, Brecevic L \& Kontrec J (1997) Vaterite growth and dissolution in aqueous solution. 3. Kinetics of transformation. J. Cryst. Growth 177: 248-257

Kuba T, Murnleitner E, vanLoosdrecht MCM \& Heijnen JJ (1996) A metabolic model for biological phosphorus removal by denitrifying organisms. Biotechnol. Bioeng. 52(6): 685-695

Landmeyer JE, Vroblesky DA \& Chapelle FH (1996) Stable carbon isotope evidence of biodegradation zonation in a shallow jet-fuel contaminated aquifer. Environ. Sci. Technol. 30: 1120-1128

Larsen TA \& Gujer W (1995) The implementation of biokinetics and conservation principles in ASIM. Wat. Sci. Tech. 31(2): 257266

Maillacheruvu KY \& Parkin GF. (1996) Kinetics of growth, substrate utilization and sulfide toxicity for propionate, acetate, and hydrogen utilizers in anaerobic systems. Water Environ. Res. 68(7): 1099-1106

Maurer M \& Rittmann BE (2003). Novel predictions of the CBC model for natural attenuation of BTEX, in preparation.

Maurer M \& Rittmann BE (2004) Modeling intrinsic bioremediation for interpret observable biogeochemical footprints of BTEX biodegradation: the need for fermentation and abiotic chemical processes. Biodegradation 15: 405-417.

NRC (National Research Council (1993). In Situ Bioremediation: When Does It Work? National Academy Press, Washington, D.C.

NRC (National Research Council) (2000). Natural Attenuation for Groundwater Remediation. National Academy Press, Washington, D.C.

Orhon D, Sozen S \& Artan N (1996) The effect of heterotrophic yield on the assessment of the correction factor for anoxic growth. Water Sci. Technol. 34(5-6): 67-74

Plummer LN \& Busenberg E (1982) The solution of calcite, aragonite and vaterite in $\mathrm{CO}_{2}-\mathrm{H}_{2} \mathrm{O}$ solution between 0 and $90{ }^{\circ} \mathrm{C}$ and an evaluation of the aqueous model for the system $\mathrm{CaCO}_{3}-$ $\mathrm{CO}_{2}-\mathrm{H}_{2} \mathrm{O}$. Geochim. Cosmochim. Acta. 46: 1011-1040

Pope GA, Sepehrnoori K, Sharma MM, McKinney DC, Speitel GEJ \& Jackson RE (1999) Three-Dimensional Napl Fate and Transport Model (Utchem). EPA, United States Environmental Protection Agency, EPA/600/R-99/011, February 1999, CINCINNATI, OH 45268. EPA/600/R-99/011

Postma D (1993) The reactivity of iron-oxides in sediments a kinetic Approach. Geochim. Cosmochim. Acta 57(21-22): 5027-5034

Rafai HS, Newell CJ, Gonzales JR, Dendrou S, Kennedy L \& Wilson JT (1998) "Bioplume Iii - Natural Attenuation Decision Support System - User's Manual Version 1.0". EPA, United States Environmental Protection Agency, Washington

Reardon KF, Mosteller DC \& Rogers JDB (2000) Biodegradation kinetics of benzene, toluene, and phenol as single and mixed sub- strates for Pseudomonas putida F1. Biotechnol. Bioeng. 69(4): 385-400

Reichert P, Borchardt D, Henze M, Rauch W, Shanahan P, Somlyody L \& Vanrolleghem P (2001) River Water Quality Model no1 (RWQM1): II. Biochemical process equations. Water Sci. Technol. 43(5): 11-30

Revesz K, Coplen TB, Baedecker MJ, Glynn PD \& Hult M (1995) Methane production and consumption monitored by stable $\mathrm{H}$ and $\mathrm{C}$ isotope ratios at a crude oil spill site, Bemidji, Minnesota. Appl. Geochem. 10: 505-516

Rickard D (1995) Kinetics of fes precipitation. 1. Competing reaction-mechanisms. Geochim. Cosmochim. Acta 59: 43674379

Rickard D (1997) Kinetics of pyrite formation by the $\mathrm{H}_{2} \mathrm{~S}$ oxidation of iron (II) monosulfide in aqueous solutions between 25 and 125 degrees C: the rate equation. Geochim. Cosmochim. Acta 61: 115-134

Rickard D \& Luther GW (1997) Kinetics of pyrite formation by the $\mathrm{H}_{2} \mathrm{~S}$ oxidation of iron(II) monosulfide in aqueous solutions between 25 and 125 degrees $\mathrm{C}$ : the mechanism. Geochim. Cosmochim. Acta 61: 135-147

Rickard D, Schoonen MAA \& Luther GW (1995) Chemistry of iron sulfides in sedimentary environments. In: Vairavamurthy MA \& Schoonen MAA (Eds) Geochemical Transformations of Sedimentary Sulfur, Vol. 612 (pp 168-193), American Chemical Society, Washington

Rittmann BE, Bae W, Namkung E \& Lu CJ (1987) A critical evaluation of microbial product formation in biological processes. Water Sci. Technol. 19: 517-528

Rittmann BE \& McCarty PL (2001) Environmental Biotechnology: Principles and Applications. McGraw-Hill, New York

Ryan JN and Gschwend PM (1991) Extraction of iron-oxides from sediments using reductive dissolution by titanium(III). Clay. Clay Miner. 39(5): 509-518

Schäfer D, Schäfer W \& Kinzelbach W (1998a) Simulation of reactive processes related to biodegradation in aquifers. 1. Structure of the three-dimensional reactive transport model. J. Contam. Hydrol. 31: 167-186

Schäfer D, Schäfer W \& Kinzelbach W (1998b) Simulation of reactive processes related to biodegradation in aquifers. 2. Model application to a column study on organic carbon degradation. $\mathbf{J}$. Contam. Hydrol. 31: 187-209

Schink B (1997) Energetics of syntrophic cooperation in methanogenic degradation. Microbiol. Mol. Biol. R. 61(2): 262-280

Smith MR \& Mah RA (1980) Acetate as a sole carbon and energy source for growth of Methanosarcina strain 227. Appl. Environ. Microbiol. 39: 993-999

Smolders GJF, Vandermeij J, VanLoosdrecht MCM. \& Heijnen JJ (1995) A structured metabolic model for anaerobic and aerobic stoichiometry and kinetics of the biological phosphorus removal process. Biotechnol. Bioeng. 47(3): 277-287

Stumm W \& Morgan JJ (1996) Aquatic Chemistry. John Wiley \& Sons

Stumm W \& Sulzberger B (1992) The cycling of iron in natural environments - considerations based on laboratory studies of heterogeneous redox processes. Geochim. Cosmochim. Acta 56(8): 3233-3257

Svensson U \& Dreybrodt W (1992) Dissolution kinetics of natural calcite minerals in $\mathrm{CO}_{2}$-water systems approaching calcite equilibrium. Chem. Geol. 100: 129-145

Thauer RK, Jungerman K \& Decker K (1977) Energy conservation in chemotrophic bacteria. Bact. Rev., 41: 100-180 
White WB (1997) Thermodynamic equilibrium, kinetics, activation barriers, and reaction mechanisms for chemical reactions in Karst Terrains. Environ. Geol. 30: 46-58
Zehnder AJB, Ingvorsen K \& Marty T (1982) Microbiology of methane bacteria. In: Huges et al. (Ed) Anaerobic Digestion 1981. Elsevier, Amsterdam 